\title{
Enhancing education effectiveness: In which 'education' should society's hard-earned money go?
}

\author{
Muyanja Ssenyonga ${ }^{a}$ and Ely Susanto ${ }^{b}$ \\ ${ }^{a, b}$ Master Program in Public Administration, Department of Public Policy and \\ Management, FISIPOL, UGM \\ amuyanja.ssenyoga@gmail.com, belysusanto@ugm.ac.id
}

\begin{abstract}
This paper is exploratory in nature, and has the objective of examining the determinants of educational effectiveness as a pathway to identifying how countries should allocate public spending on education. The paper is based on a review of extant literature and analysis of statistics on education attainment, employability, and rate of unemployment of workforce with different levels of educational attainment. Tentative findings point to both national context and international factors playing an important in influencing the proportions of public spending on education should go to elementary, non-vocational higher education and vocational education. National context determines the policy priorities, which education is only one of the sectors that ensures the achievement thereof; underpin cultural, social and political and economic realities that determine societal values, traditions that must be acquired and transferred from one generation to the next, skillsets that are needed to create a competent workforce with the ability to harness a country's resources optimally, absorb and apply new ideas that are developed in other societal contexts which with some modifications can help in providing solutions to problems at the sub national and national level. There is also some important role for international cooperation as well. Different facets of education that range from educational structure and system, curriculum, teaching and learning process, performance evaluation and remuneration, to training and education, infrastructure, to educational institutions-corporate sector relations play their respective roles in influencing the quality and effectiveness of an educational system as reflected in the contribution its products make to an economy and society. Thus, increasing educational effectiveness requires not only to look internally for solutions to all a country's education problems, but also take advantage of the globalized, interconnected, and interdependent world for effective best practices, which upon modification to suit local and national contexts can be adopted initially in pilot schemes, that are eventually scaled up.
\end{abstract}

Key words: Education; Effectiveness; Skillset; Policy; Cognitive; Socioemotional; Employability

\section{Introduction}

The overarching goal of education policy should be to nurture the development of holistic individuals, create an enabling environment that facilitates the provision and renewal of skills, knowledge and competences vitally important for a country's sustainable social and economic development, and by extension societal welfare. The role of education in society has never beenmore important than in today's increasingly 
shaped and driven gig economy (Petriglieri, Ashfor, \& Wrzesniewski, 2018) ${ }^{\mathrm{iii}}$ that is creating millions of new jobs that demand entirely new skillsets as it is destroying millions of traditional ones, which contemporary workers acquired at such a hefty cost in terms of cost, time, and effort (Rustat-Conference, 2016). Thus, to remain employable, today's workforce will have to learn new skills, the tasks of which are still evolving, and will continue to change at even faster pace as the artificial intelligence, Internet of things (IoT), machine learning and Data analytics driven Industrial revolution 4.0 economy takes shape (Dokko, Mumford, \& Schanzenbach, 2015). Competence and capabilities while will remain important, are no longer sufficient to one to remain employable, let alone competitive, agility, autonomy, adaptability, versatility (McKinsey Global Institute, 2016), and lifelong learner are features that are increasingly defining an effective workforce (Barriere, Owens, \& Pobereskin, 2018), (De-Steffano). Regrettably, education provision like other sectors that do not directly contribute to production has often faced deep cuts in government spending, often at the insistence of donor agencies such as the World Bank and International Monetary Fund. That said, many developing countries continue to spend high percentage of their national budgets on primary and secondary education, and to a certain degree, higher education.

Nonetheless, increasing expenditure on elementary education, which has been able to achieve 100 percent enrollment rate even in the least developed of countries, has been achieved at the cost of dramatic decline in educational quality as well as decline in public funding allocated to higher education as deep cuts, rationalization and liberalization took effect (Kintu, 2016). Gains in public expenditure on universal primary education have at best been mixed, if not illusory, while disengagement from tertiary education has meant that the state has in some way abrogated its basic function of preparing its citizenry for the knowledge economy (Hanushek \& Ludger, 2015). The Indonesian constitution mandates the government to spend at least $20 \%$ of its annual expenditure on education. Increase in expenditure has sustained 9-year compulsory education program, that has made possible almost Universal enrollment in elementary schools, which coupled with support at subnational level, is being scaled up to secondary education.

The problem is, however, rising expenditure has not solved some of the fundamental problems the country's education faces, inter alia, rising unemployment of tertiary education graduates, including those attending vocational institutions that are purportedly expected to produce ready to employ graduates. The paper explores determinants of educational effectiveness as a pathway to identifying how countries should allocate public spending on education. The paper is based on a review of extant literature and analysis of statistics on education attainment, employability, and rate of unemployment of workforce with different levels of educational attainment. The rest of the paper is presented as follows. Section two discusses theoretical and empirical groundwork for the paper, followed by section three that takes a glance at rising cost of education and its implications. Section four looks at the benefits of Germany apprenticeship system, followed by section five that discusses determinants of education quality, education cost, and employability, while section six 
makes presents a brief account of Indonesia's experience in universal education provision and effectiveness. Section seven takes a deeper dive at the contentious of apportioning public expenditure on education among the three broad levels of elementary, non-vocational higher education, and vocational education. Section eight sums up the arguments for public spending on each level of education. Section nine concludes the article.

\section{Theoretical and empirical perspectives on education and effectiveness}

\section{a. Education effectiveness}

Education plays a crucial role in the creation, acquisition, transfer, and translating of knowledge, skills, and technology that are necessary for economic productivity. The rapid pace of developments in drivers of knowledge, skills, and technology in an increasingly globalized products and services market implies that renewal of knowledge and skills through education and training is imperative. Moreover, acquisition of skills and competences that enable an individual to earn stable incomes on completing studying, makes education one of the most crucial determinants of social mobility and societal equality(Altzinger, Cuaresma, Sauer, \& Wu, 2015; Arifin, 2017; Cremer, H., De Donder, P. \& Pestieau, 2009; European Commission, 2014; Rodríguez-Pose \& Tselios, 2008; Wolf, 2002).

Thus, given the great and fundamental importance that education plays in promoting the creation of a productive economy, promotion of efforts that foster welfare of the citizenry, social mobility and equality, the government must play a pivotal role in education delivery. Education being a human right for all individuals makes the government as the main custodians of human rights of individuals, groups of individuals, and society at large, one of the most, if not the most important party that must play a primary role in determining the philosophical foundation, direction, and delivery of education service provision ${ }^{\text {iv }}$. It must emphasize though that the important gauge of the effectiveness of an educational system does not only lie in the number of graduates that leave gates of its different levels of its education system, rather the employability of the graduates in the labor market, and ability to contribute to societal social, economic, even political development. In other words, an effective educational system produce graduates who perform well on measurable outcomes, but also more importantly, are equipped with higher order skills that make them productive, creative, versatile individuals who can contribute to their families, communities and society.

The World Development report (2018) refers to such capacity as the education's promise. An effective educational system should provide conducive conditions for students to attend classes (schooling) but also more importantly, space for acquiring cognitive, socioemotional, and technical skills (learning). A combination of measurable skills and other skills, by making them productive, creative, and innovative, enhance their employability as well as nurturing and development them into good individuals for society. Indeed, it is the capacity of an educational system to provide learning that enables its graduates to acquire long run, lifelong skills that equips them with the ability to contribute to economic growth through higher productivity, creativity, flexibility, tolerance, and better health (The World Bank, 2018). 
One key factor that determines the effectiveness of an education system is the degree of employability of education system graduates. Employability reflects the degree to which the system equips students with requisite cognitive, socioemotional, and technical skillsets that are required for individual development (tolerant, team player, flexible), the job market (productivity, creativity, adaptability and flexibility), and societal development and renewal (productivity, good national and global citizenship (Mortimore, 1997)).

Determinants of effective education system include social, economic and cultural conditions that favor the existence of motivated and prepared students; quality teachers thanks to a recruitment process that taps the best, pays them sufficiently to remain in the profession, provides them with opportunities to achieve personal social, economic, intellectual and professional development, creates conditions for learning from peers about developments in teaching materials including text books and teaching aids; expectations of teachers, parents and students (Weber, 1971); home and neighborhood environment; educational facilities; leadership of educational institutions (vision, strategy and direction, and management of resources); students achievements and attitudes as learners; teacher attitudes towards the school and students as learners; parents and community attitudes toward the school and education (Clark, Lotto, \& McCarthy, 1980), (Van der Werf, Opdenakker, \& Kuyper, 2008).

Meanwhile, determinants of effective educational institutions include a gamut that encompass educational institution goals, curriculum, instruction, assessment and evaluation, classroom management, community involvement, leadership, existence of safe and orderly environment, student motivation, expectations, teacher professional development, social skills, existence of quality control and assurance, and coordination between educational institution principal, staff, and parents (Saleem, Naseem, Ibrahim, Hussain, \& Azeem, 2012)

\section{b. Private and social return on investment in Education}

For many developing and least developed countries, education offers an opportunity to reduce rampant poverty and squalor. This is because investment in education by increasing economic growth, productivity, hence development, has been associated with poverty reduction and income inequality, with developing countries expected to reap higher rewards from such investment due to the initial low education level (Atkinson \& Messy, 2013; Buchinsky, 2000; Checchi, 2004; De Gregorio \& Lee, 2002; Hastings, Madrian, \& Skimmyhorn, 2012; Koda \& Yuki, 2012; Rehme, 2007; Sylwester, 2000, 2002; Unesco, 2015; Williams, 2007).

However, the role of the government in education is not only limited to providing a conducive climate for those involved in providing educational services through the issuing of laws and regulations, but is by and large, involves direct participation in the delivery (man power panning which lays the foundation for national educational service delivery policy on curricula and programs; establishing, running and managing public educational institutions, providing subsidies to educational institutions in forms of capitation grants that are based on enrollments, extending need-based scholarships to increase access of education to capable 
but financially underprivileged children and students hailing from poor sections of society, paying for salaries and allowances for teachers and staff in both state and private educational institutions).

It is not surprising therefore that state involvement is considered pivotal for education quality, and by extension the quality of human resources a nation has. Nations where state involvement in education is high and covers all aspects of the education provision process ranging from regulation and supervision, accreditation, to managing state owned educational institutions, with some exceptions that are generally confined to developing countries, tend to have high education quality, high quality of human resources, and by extension, fair income distribution and public welfare. Nordic countries are a good case in point, in this regard.

In line with that argument, overall un-aggregated public spending is found to have negative influence on economic growth through the crowding effect, distortion of markets, and rent seeking activities such spending generates (Conte \& Darrat, 1988); (Carlstrom \& Gokhale, 1991); (Engen \& Skinner, 1997); (Davies, 1997); (Guseh, 1997); (Grier \& Tullock, 1989); Burton, 1999; and (Barro R. J., 1990).

However, in a research by Alexio (1996) in transition economies on the government spending on the provision of public goods that included capital formation, development assistance, private investment and trade-openness, had positive and significant impact on economic growth. Similar results were obtained by (Epstein \& GINTIS, 1995), (Burton, 1999), (Kelly, 1997), (Alexiou, 2007), (Aschauer, 1989), and (Asimakopoulos \& Karavias, 2016). That said, results on the influence of government expenditure in education on economic growth and development have been found to be strong and significant (Barro R. , 1991), (Roubini \& Sala-i-Martin, 1991); (Birdsall, Ross, \& Sabot, 1995).

Free access to Education, a policy adopted in some developed nations that are by and large characterized by social democracy inclination such as Nordic countries, Germany, Austria, Norway, among others, has contributed to the development of highly educated work force and population that has become the envy of other nations, developed and developing alike. In such countries, governments, at both local, state, and national level, contribute their share to financing education of citizens. Even in the United States, renowned for its preference for private enterprise over public sector ${ }^{v}$, there is large expenditure of state governments in tertiary education as federal statute mandates every state to be allocated resources to establish and manage a University (Morrill \& Lincoln, n.d.) ${ }^{\mathrm{vi}}$.

\section{Indonesia's experience in providing universal education provision and effectiveness}

Indonesiae s experience offers good food for serious thought on balancing the two equaling challenging objectives of education policy. Indonesia has in place a 9-year mandatory universal education program, which was supposed to have been extended to 12 years in 2016 . Under the program, the government meets tuition costs for students as well as school pays for school operations, while parents pay for living costs and uniforms. While efforts are under way to lengthen the government hand in the provision of free education to its citizens at non-tertiary levels, liberalization of tertiary education, has become an 
established fact. Students attending public Universities and other institutions of higher learning pay tuition, albeit lower than in private educational institutions as the government subsidizes all students through paying for lecturer"es salaries, allowances, education and training, and construction and maintenance of facilities.

The Indonesian government policy on education seems to be based on the premise that non tertiary education being foundational is very vital for creating citizenry that is informed, hence receptive to government policies on such issues as health, sanitation and hygiene, adoption of groundbreaking innovations in agriculture, and playing an active role in participative decision making that is the cornerstone to democracy. National educational law No. 20/2003, which in effect delegated decision making on key issues that pertain to school operations and management to school units under the stewardship of school principals in collaboration with school committees, which represents teachers and parents serve as members. School committees are tasked with providing advice on decision making on education related issues, financial support and concepts on education delivery, provide oversight over the implementation of transparency and accountability in education financing and service delivery, serve as intermediary between the community on one hand and peoplees representatives and administration, on the other. At the district/municipality government level, schools are under the oversight of a board providing functions that are similar to those of the school committee (Bayhaqi, 2004; Jalil \& Idrees, 2013).

While decentralization has led to improvement in availability and access services, and in some cases, performance on scores (mathematics and reading aptitude), it has unwittingly exacerbated social and regional disparity in education delivery and performance, it has also brought to the fore concerns about the sustainability of the programs due to the larger burden relinquished to local governments for post Junior secondary school education, differential management capacity, and ineffective school committees. Needless, side effects of education decentralization, have energized critics of the policy by claiming that such outcomes justify their concerns about the unintended consequences of the rising tide of ,commercialization ${ }^{\text {ce }}$ of education service provision (Bayhaqi, 2004; Behrman, Deolalikar, Behrman, \& Deolalikar, 2002; Bjork \& Bjork, 2018; Jalil \& Idrees, 2013; Kristiansen \& Pratikno, 2006; Leer, 2016; Martinez-bravo, 2017; Nasution, 2016; Planner et al., n.d.; Psacharopoulos, 2006; Report, Seminar, Implementation, \& Management, 2006; Republic of Indonesia, 2011; Samosir, 2008; Shavit, 2000; Simatupang, 2009; Tobias \& Wales, 2014; USAID, 2008; Bandur, 2012).

\section{Where should a country invest its hard-earned revenue to enhance education effectiveness?}

It must be noted however that high government expenditure on primary education and lower secondary education that is common in many developing countries and was encouraged by efforts to achieve one of the Millennium goals that calls for increased access to universal primary education and reducing gender inequality in access to education (2000- 
2015), is very much in stark contrast with the policies that are pursued in developed nations that have rates of unemployment of tertiary education graduates that are generally lower than those from lower education levels. Government spending in developed nations is lopsidedly biased in favor of tertiary and continuing training and education for adults such as Sweden, Switzerland, Norway, and Germany.

Figure 1. Rate of return on human capital investment by age bracket

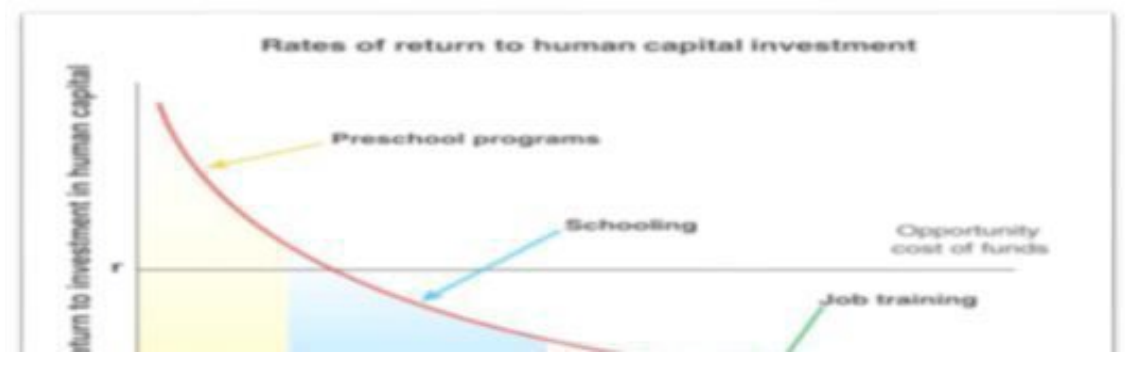

Source: Sachs 2015

Nonetheless, such a policy may also be underpinned by strong theoretical and empirical underpinning such as the notion propounded by Jack Hechman (Figure 1). Jack Heckman, notes that investment in an individual's education has higher returns at an early age than at older age due to the opportunity that early education gives the child to develop crucial cognition and scholastic aptitude, socialization skills, and physical wellbeing (Sachs, 2015).

Yet as Sachs (2015) notes, tertiary education is important for developing countries to enable them create the critical mass of teachers, engineers, technical workers, public policy experts and practitioners that can support economic development efforts. Higher education is also required for a country to enhance its capacity to absorb, and create new technology (technological absorptive capacity), hence is pivotal for a country to accelerate its efforts to achieve technology catch-up. By increasing expenditure on higher education, which should lead to increase in higher education stock, would contribute in the order of 12.2 percent toward effective and efficient use of inputs, increase GDP growth by 0.63 percent, arising from increase in GDP per capita 0.24 percent in long run steady state and 0.39 percent in technological catch up in the first year. Such achievements would translate into an increase of 3 percent after five years in incomes, and eventually 12 percent (Bloom, Canning, \& Kevin, 2006).

Thus, given financial constraints that many countries both developed and developing countries face today, not a few are in the process of reducing state expenditure in education in general and tertiary education in particular. Good examples include United Kingdom (Llanes, 2010), Sweden (which imposes tuition for students coming from Non-EU and EEA 
member countries), and other nations with the exception of Germany, Iceland, Norway, and Finland. Thus, formidable difficulties many nations face in securing necessary funding to support tertiary education, has compelled many countries to embark on liberalization of education provision. This is achieved through increasing avenues that educational public institutions have in generating revenues (allowing several admission channels that allow for use of academic performance and financial capacity common in Indonesia today, allowing state institutions to engage in economic activities that are ostensibly not very distinct from education service provision (Indonesia is a good case in point), allowing domestic educational institutions to establish linkages with foreign educational and research institutions with the hope of increasing their international exposure to generate students exchange and cooperation in other education provisions activities that generate revenues (Indonesia is a good case in point here).

Surprisingly, the World Bank has also shown the tendency of being more interested and keen to support primary and secondary education than tertiary education. This is reflected in statistics on World Bank expenditure that showed a decrease of more than 100 percent in education sector spending worldwide from, 17 percent during 1985-1989 period to a mere 7 per cent during 1995-1999 period (Bloom, Canning, \& Chan, 2009).

Higher education, has led to gradual liberalization of the subsector. In Indonesia, liberalization of higher education provision has by and large gone hand in hand with commercialization, and there is no better testament of that than Indonesia education policy. In 2003, the Indonesian reformation regime under President Megawati enacted the National educational law No. 20/2003, which in effect delegated decision making on key issues that pertain to school operations and management to school unit under the stewardship of school principals in collaboration with committees on which represents teachers and parents serve as members.

While efforts are under way to lengthen the government hand in the provision of free education to its citizens at non-tertiary levels, liberalization of tertiary education, has become an established fact. Students attending public Universities and other institutions of higher learning pay tuition, albeit lower than in private educational institutions as the government subsidizes all students through paying for lecturers's salaries, allowances, education and training, and construction and maintenance of facilities.

However, even prior to that students who gain admission to tertiary institutions, including those that are state owned, are supposed to pay tuition, which is generally lower than that applicable in private institutions. Scholarships are awarded on the basis of need (need based subsidies support students from poor family backgrounds), regional disparity reduction (given to students that come from regions that are categorized as underdeveloped which by and large are in Eastern part of the country).

Plans are underway for foreign education institutions to be allowed to operate in Indonesia, a prospect which if implemented will open the flood gates of Indonesian educational system not only to educational institutions that are incorporated abroad, but also importantly, foreign systems, philosophical foundations and values that underpin their evolution and development. 
It is not surprising that the decline in public resources that are allocated toward financing the creation of an opportunity for students who secure admission on the basis of financial capacity has generated demand for tertiary education that is not underpinned by the capacity of an individual to undergo undergraduate studies, rather ability to pay. There is little doubt though, that as the number of graduates soars, the quality has tended to decline. Yet, in order for citizens of a nation to make informed decisions, achieve social, economic, and cultural goals, nurture and develop contextually appropriate societal protection programs, ensure better leadership and foster equity, what is needed is not quantity but quality education.

Thus, there is a general trend in the provision of education that is characterized by: public expenditure at elementary and lower secondary level maintained at high level, albeit most of it going toward paying salaries and allowances of teachers rather than improving quality of educational facilities and scholastic materials (primary education in state schools is free but local governments do not allocate sufficient funds for text books, instead require parents to download them from websites that are run by the ministry of education free of charge, and the central government allocates funding to support school operations, as well as payment of teachers ${ }^{\text {ee }}$ salaries since teachers are civil servants or serving as temporary teachers that receive piece based honorariums).

On the other hand, the state facing other equally pressing development demands, is increasingly opting to disengage discretely by gradual liberalization of state educational institutions, thereby increasing the role of the supply and demand for education in determining the price that students pay. The consequence that is unavoidable has been the mismatch between the long term human resource development goals of the government that are manifested in manpower planning and detailed trajectory of achieving them, and the short term annual budget austerity driven educational provision realities that emphasize supply of whoever can pay the right price, hence decoupling education service delivery from long term development goals that such a process creates. consequences are as vivid as they are humbling. Like in other developing and emerging countries that have adopted the Universal pre tertiary education mantra as a panacea for all education problems, the drastic decrease in the burden individuals (families) and by extension society bear, has not only fueled a drastic increase in enrollments as envisaged but also created a huge supply of students that state Universities cannot accommodate thereby leaving a huge lucrative market that private corporate education Inc. has exploited to the utmost to recruit, produce, and release graduates at rates that employment creation can hardly match. Rising unemployment at all levels has been the inevitable outcome.

Statistics on unemployment rates in Indonesia, provide interesting reading for a number reasons. First, open unemployment has been declining over the last decade from 9.1 percent in 2007, 6.2 percent in 2013, and 5.5 percent in 2016 (Figure 2). Secondly, the current downward trend was a break from the upward trend in unemployment that started in 1996 (4.4 percent) and had its peak in 2005 (11.2 percent). Thirdly, based on 2013 figures, 47.6 percentage of those categorized as unemployed had primary educational attainment; 
43.6 percent had secondary school education, with prospects getting worse since 2004 when a downward trend in unemployment in this category reversed to trend upwards; and 7.7 percent of those unemployed had tertiary education. Fourthly, while the general trend of those unemployment with tertiary education shows a downward trend (1991-2013), breaking down that trend into 1991-2002 and 2003-2010, shows evidence that unemployment of people who qualify to be working, and were searching work during the latter period, was upward.

\section{Figure 2. Unemployment by education attainment, 1991-2013}



Source: BPS

The persistence of high unemployment has been blamed on relatively lower economic growth (5.0 percent) that has characterized late $1990 \mathrm{~s}$ and $2000 \mathrm{~s}$ and projected to continue in the medium term, compared with 7 percent during late 1980s and early 1990s) Figure 3); anemic global economic growth which has led to a decline in commodity prices, low even stagnant growth in the manufacturing sector, and growth in employment in low end unproductive trade and services sector (ILO, 2016). What is also cause for concern is that Indonesian economic growth is currently lagging the performance of other ASEAN seven economies (Figure 4). 
Figure 3. Trend in Economic growth, 1980-2015

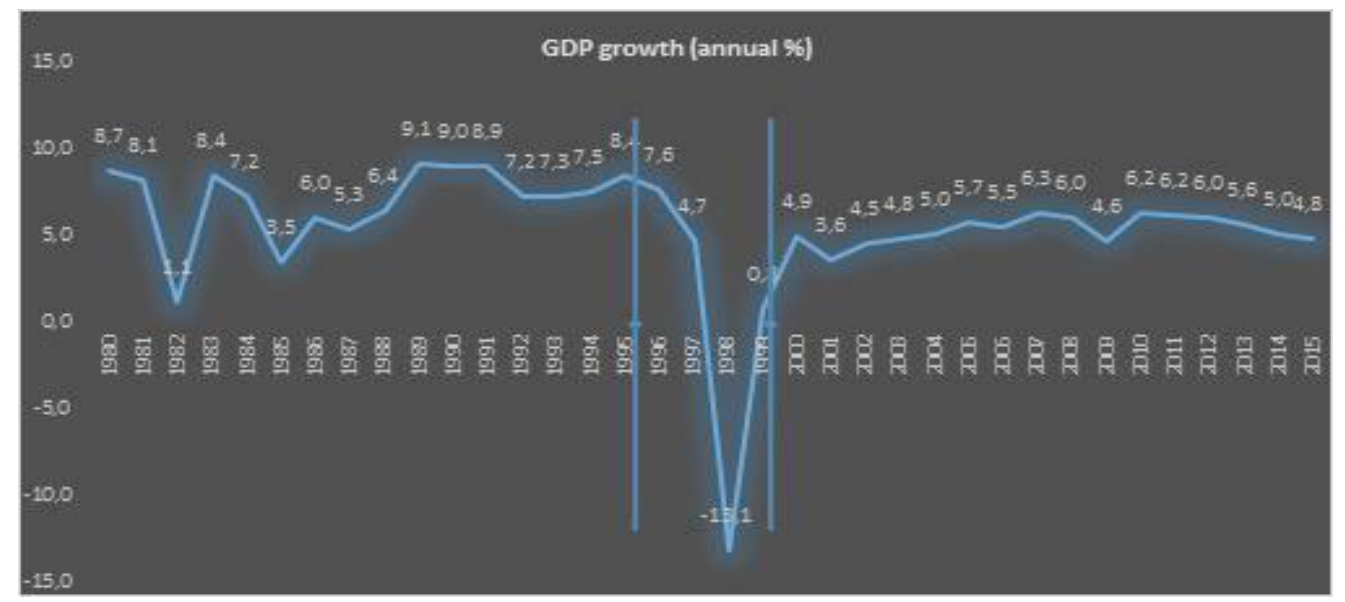

Source: World Development Indicators(WDI)

Figure 4. Economic Growth 2017, Indonesia compared to other 7 ASEAN members

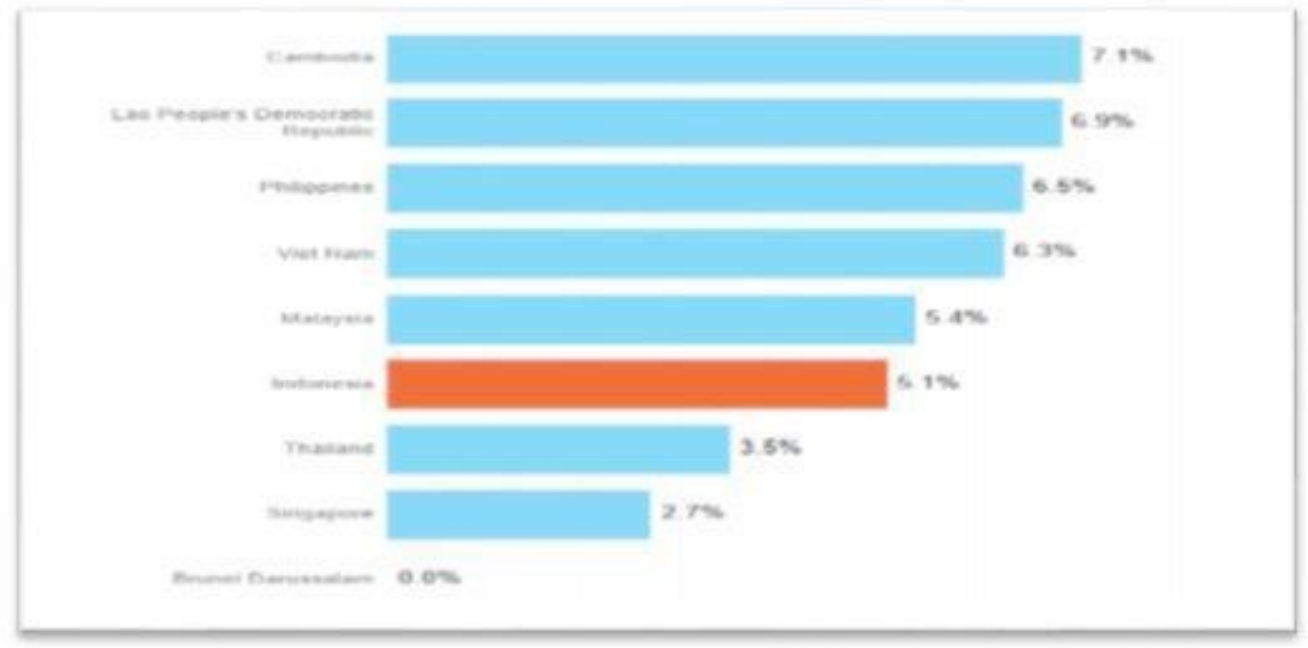

Source: ADB

Other factors, include automation and rise in labor productivity since the implementation of Manpower law No.13/2003 that increased hiring and firing cost of labor; de-industrialization process that has been attributable to imports from China since its entry in WTO in 2001, and imports from ASEAN member states since ASEAN Free Trade area (2004) and subsequent ASEAN Economic Community (December 2015), largely due to the free merchandize and services trade regime in place in Indonesia. That said, given the persistent increase in the unemployability of people with vocational education over time, there is no doubt that structural factors are playing an important part in the rising misalignment between skillsets that vocational education institutions equip with students and 
skills that the labor market needs. This is because socioeconomic outcomes from vocational education training seems to be contrary to expectations and results of previous research that consider it one of the most effective way to achieve social mobility (Altzinger et al., 2015; Dadang Kurnia, 2015; Giret, 2011; Krueger \& Kumar, 2004; Lehmann, 2009; Nilsson, 2010; Shavit, 2000; (Sue, Bathmaker, Gale, Hodge, \& Parker, 2017).

Fifthly, the higher education attainment, all other factors remaining constant, is associated with lower unemployment. People with only primary education have the highest probability of being unemployed, and remaining that way; followed by individuals with secondary education; and people who have tertiary education are the least likely to join the burgeoning unemployment.

An even better portrait of unemployment is discernible from statistics on people who were categorized as unemployed with senior high school, vocational training, Diploma, I, II, and II/ and academy training (Figure 5).

\section{Figure 5. Unemployment of individuals with vocational training, 2004-2014}

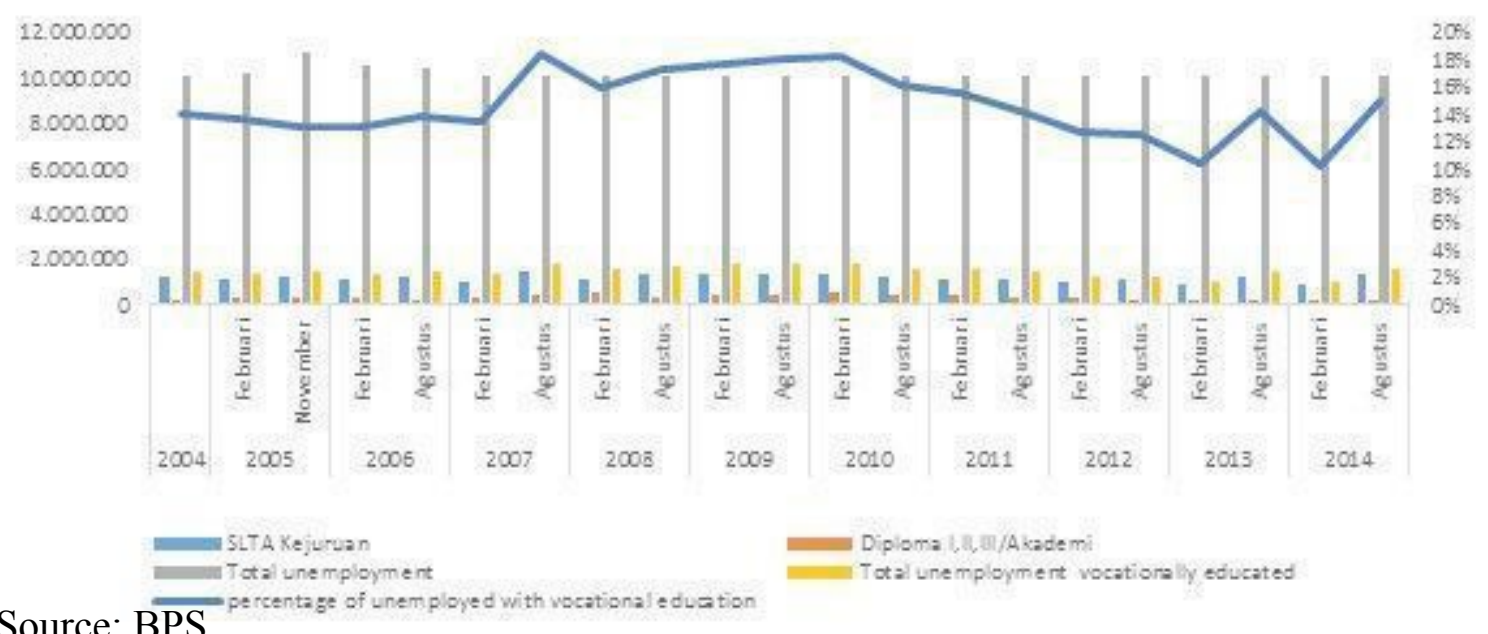

The downward trend in percentage of individuals who were categorized as unemployed which begun in August 2010, seems to falter in August 2013, recovers in February 2014 only to decline again in August 2014 (Figure 5).

Overall, however, there is no denying the fact that unemployment of individuals who have vocational training remains generally high. This is contrary to expectations of those who opt to go for vocational training as well as experts on employment and education. Though in August 2014, unemployed among those individuals who had vocational training was 18 percent, it decreased to 15 percent, in a trend that shows seasonal variation. The rate of open unemployment of vocational high school graduates is interesting given the fact that one of the key motivations for students to join such institutions is the expectation of obtaining work as soon as they finish their studies. In fact, many low income end middle income parents who consider tertiary education a burden without the guarantee that students will obtain employment as soon as they graduate, opt for vocational high schools for that simple reason. To that end, developments in the trend of unemployment among 
graduates of vocational high schools gives a good portrait on the general state of unemployment in Indonesia. The decline in unemployment that occurred during 2007-2013, has since faltered and since 2014 the trend reversed and is currently tending upwards. Data obtained from Kompas (May 2, 2017) shows that while unemployment of vocational high school graduates declined from 13.3 percent of total labor force in 2007 to 6.0 percent $\mathrm{i}$ vocational school graduates were unemployed, a value that rises to 9.1 percent and 9.8 percent in 2015 and 2016, respectively. Thus, while individuals with university education was 7.7 percent of those unemployed, the percentage of those with vocational training remains more than twice that.

\section{Lessons learned on apportioning public spending by education level relative to benefits generated to society}

The increasing stringent national budgets mean that public money must be spent in such a manner that every Rupiah should go to a sector or sub sector where it generates the most social return. Injecting trillions of Rupiah in Universal primary and secondary education, has been associated with enhancing literacy in the general population which is vital for a generally informed population necessary for participatory decision making. However, such investment, it must be stressed, needs to be made with the knowledge that the opportunity cost is lower investment in other forms of education that include higher education in general and specialist or vocational education in particular.

Higher education attainment equips learners with expertise that does not only enhance the contribution an educated individual makes toward achieving societal goals such as basic and applied researchers that are vital for groundbreaking society problems solving innovations and inventions; human resource with professional skills to undertake corporate and government management and administration tasks; historians, ethnographers and linguists who study developments and evolution in the dynamics of various aspects of society that range from events in the past and how inform present day events and in turn the future, aspects of microcosm of society in the context of values, traditions, customs, traditions, social, economic, political and cultural organization and how such influence individual and group behavior, and the role that languages as representation of "how people acquire their knowledge about languages as manifested in sounds (phonetics, phonology), words (morphology), sentences (syntax), and meaning (semantics), and how this knowledge interacts with other cognitive processes, how it varies across speakers and geographic regions, and how to model this knowledge computationally" (Macaulay n 2013, figures for 2014-2016 show a general upward trend. In 2014, 6.1 percent of \& Syrett, n.d.), respectively.

Nonetheless, investing disproportionately too much in higher education has its downside that include exacerbating income inequality, creating enclaves of educated elites in a sea of mediocrity- educated general population, ivory towers that pump out theories and even proven and tested experiments that are far removed from what society needs, which in 
turn gravitates towards handing over the reins of knowledge as power to the few, leaving the majority in perpetual systematized sycophancy and subservience.

However, there is a middle pathway too, which is taking some good lessons from countries such as Germany that have had tremendous success in vocational education to align education system outcomes to labor market needs (skillsets). And it is not only the government that pays for the education, industry and commerce is also keen to pay its share as long as it has an opportunity to contribute to the curriculum social schools use in conducting their education. Industrial organization practitioners also serve as members of the teaching staff to reduce the wide gap between highly theoretical lessons that members of academia provide (based on text book theories and research) and practical realities at factory floors, farming fields, and banking and insurance institution changes, with the implication that courses that are taught do not depend on the school ${ }^{\text {ee }}$ s pre commitment to employ academic staff but the relevance of skillsets that courses contain and transfer to students and by extension to the labor market, both current and in future.

That said, there is no education system, which can enhance education effectiveness by investing all its money into one form of education, whether it is pre higher education, higher education or vocational education. While each has its role in providing requisite skillsets in society, they differ in level and spread of impact and cost to direct beneficiaries and society in both the short and long term. To that end, it is society's duty and responsibility to determine the best way to apportion its education expenditure in such way that it achieves its current and future human resource needs and societal wellbeing. Making such a decision does not only depend on policy makers in government but also academia, civil society, and general public. One does not need to remind us all that in an interdependent and interconnected world we live in today, there is rarely any need to reinvent the wheel. Proved and tested effective educational policies and programs, are abound and it is upon us to have that the strong will and wisdom to overcome parochial populism that puts nationalist cum populist ideas always at loggerheads with those from neighboring, and foreign nations, regardless of quality, relevance, and effectiveness.

Specially with regards to education policy, it is important to underline the fact that enhancing efficiency of an education system is not a quick fix, text book style, let alone political-expedience driven endeavor. On the supply side, pre requisites include motivated and prepared students with positive attitude toward studying and achievement at school; quality teachers who are recruited from the best brains in the land, trained in pre service programs that are controlled by the government or other competent authority; with positive attitude toward students and teaching, which are supported through mentoring, access to professional networks, collaborations and an environment that elicits continuous improvement (Crawford, 2018); sufficiently remunerated teachers availability of adequate educational facilities; good leadership with vision, goals, strategy, management of resources in educational institutions (Clark, Lotto, \&McCarthy, 1980), and in education offices at subnational and national level (Rosenholtz, 1985); expectations of teachers, parents, and students to succeed; community support for learning (Saleem et al. 2012; Weber, 1971). 
back offices and front offices. It is an approach that is as dynamic as the economic structure

One cannot overemphasize the point that effective learning in educational institutions requires the existence of continuous, ample support and timely support from a quality educational policy that formulates the vision, objectives, goals, objectives and strategy of a country $^{\text {ee }}$ s education; implements and updates it, through renewal of the curricular to resonate with demand in human resources development and labor market. Meanwhile of the demand side, society as the ultimate beneficiaries must play an active part in the design, formulation, implementation of education policy, as are employers who must not only remain passive recipients of graduates but contribute to the education policy making policy, the curricular, and teaching staff that strengthen the relevancy of skills graduates acquire to skillsets required on the job and society.

\section{Conclusion and Implications}

This paper is exploratory in nature, and has the objective of examining the determinants of educational effectiveness as a pathway to identifying how countries should allocate public spending on education. Tentative findings point to both national context and international factors playing an important in influencing the proportions of public spending on education should go to elementary, non-vocational higher education and vocational education. National context determines the policy priorities, which education is only one of the sectors that ensures the achievement thereof; underpin cultural, social and political and economic realities that determine societal values, traditions that must be acquired and transferred from one generation to the next, skillsets that are needed to create a competent workforce with the ability to harness a country's resources optimally, absorb and apply new ideas that are developed in other societal contexts which with some modifications can help in providing solutions to problems at the sub national and national level.

There is also a role for international cooperation as well. Different facets of education that range from educational structure and system, curriculum, teaching and learning process, performance evaluation and remuneration, to training and education, infrastructure, to educational institutions-corporate sector relations play their respective roles in influencing the quality and effectiveness of an educational system as reflected in the contribution its products make to an economy and society. Thus, increasing educational effectiveness requires not only to look internally for solutions to all a country's education problems, but also take advantage of the globalized, interconnected, and interdependent world for effective best practices, which upon modification to suit local and national contexts can be adopted initially in pilot schemes, that are eventually scaled up. 
Notes

3. Defined by Collins Dictionary and Petriglieri, Ashford, \& Wrzesniewski(2018) as "a labour market characterized by the prevalence of short-term contracts or freelance work as opposed to permanent jobs," and a "freelance economy", respectively. Based on some estimates more 150 million people are employed work in a gig economy in North America and Western Europe, where success "comes from finding a balance between predictability and possibility, between viability (the promise of continued work) and vitality (feeling present, authentic, and alive in one ${ }^{e c}$ s work). To achieve that gig economy workers have established ,holding environments ${ }^{\text {ee }}$ around four key concepts place, routines, purpose, and people, that underpin and undergird their productivity, prevent uncertainty from turning into depressing anxieties but instead becomes vital sources of creativity and growth ${ }^{\text {ee }}$ (Petriglieri, Ashford \& Wrzesniewski(2018).

4. http://planipolis.iiep.unesco.org/upload/Zambia/Zambiaeducatingourfuture.pdf

5. Lincoln \& Morrill: Passing the 1862 Morrill Act

(http://www.vt.edu/landgrant/essays/lincoln-morrill.html)

6. In a landmark act Morrilles Act in 1862 that awarded every state public land to establish a University which initially was tasked with the role of providing education in agriculture, mechanics and military tactics. The act is considered revolutionary as it lay the foundation for the vital role public Universities play in US economy to this day as centers of excellence that provide quality education and research to US population as well as foreign nations, and reputable centers of innovations, breakthrough theories, game changing policy recommendations, that have become integral part of policy making in US governments and corporations.

\section{References}

ADB. (2009). Good Practice in Cost Sharing in Higher Education. ADB, Regional and Sustainable Development Department. Mandaluyong City: ADB. Retrieved January 10, 2017, from https://www.adb.org/sites/default/files/publication/28623/good-practicecost-sharing-financing-educ.pdf

Aghion, P., Boustan, L., Hoxby, C., \& Vandenbussche, J. (2009). The Causal Impact of Education on Economic Growth: Evidence from US. Retrieved January 11, 2017, from http://scholar.harvard.edu/files/aghion/files/causal_impact_of_education.pdf

Alexiou, C. (2007). Unraveling the „Mystery ${ }^{e e}$ Between Public Expenditure and Growth: Empirical Evidence from Greece . International Journal of Economics, 1(1), 21-31.

Aschauer, D. (1989). 1989. Is public expenditure productive? Journal of Monetary Economics, 23, 177.

Asimakopoulos, S., \& Karavias, Y. (2016) The impact of government size on economic growth: Athreshold analysis. EconomicsLetters, 139(2016), 65-68.

doi:http://dx.doi.org/10.1016/j.econlet.2015.12.010 
Barriere, M., Owens, M., \& Pobereskin, S. (2018). Linking talent to value.

McKinsey\&Company. McKinsey Quarterly.

Barro, R. (1991). Economic Growth in a Cross Section of Countries. Quarterly Journal of Economics, 106, 407.

Barro, R. J. (1990). Government Spending in a Simple Model of Endogeneous Growth. Journal of Political Economy, 98(5), 103-125. . doi:https://doi.org/10.1086/261726

Birdsall, N., Ross, D., \& Sabot, R. (1995). Inequality and Growth Reconsidered: Lessons from East Asia. World Bank Economic Review, 19(3), 477-508.

Bloom, D., Canning, D., \& Kevin, C. (2006). Higher Education and Economic Development in Africa Human Development Sector Africa Region. Harvard University. Retrieved from http://ent.arp.harvard.edu/AfricaHigherEducation/Reports/BloomAndCanning.pdf

Burton, A. A. (1999). The effect of government size on the unemployment rate. Public Choice, 99, 395-401.

Carlstrom, C., \& Gokhale, J. (1991). Government Consumption, Taxation, and Economic Activity.Economic Review-Federal Resrve Bank of Cleveland, 27(3).

Clark, D. L., Lotto, L. S., \& McCarthy, M. (1980). Secondary source study of exceptionality in urban elementary school. In Phi Delta Kappa, Why do some urban. schools succeed? The Phi Delta Kappa of exceptional urban elementary schools. Bloomington. Indiana: Phi Data Kappa and Indiana State University.

Clark, D. L., Lotto, L., \& McCarthy, M. (1980). Factors associated with success in urban elementary schools. Phi Delta Kappan, 61, 467-480.

Conte, M. A., \& Darrat, A. F. (1988). Economic Growth and the Expanding Public Sector: A Reexamination. The Review of Economics and Statistics, 70(2), 322-330.

Crawford, M. (2018, March 13). To unlock student potential in East Asia Pacific, be demanding and supportive of teachers. East Asia \& the Pacific on the rise. Retrieved from , http://blogs.worldbank.org/eastasiapacific/unlock-student-potential-east-asiapacific-be-demanding

Davies, A. (1997). Human development and the optimal size of government. The Journal of Socio-Economics, 326-330.

De-Steffano, V. (2016). The rise of the 'just-in-time' workforce»: On-demand work, crowdwork and labour protection in the 'gig-economy'. nclusive Labour Markets, Labour Relations, ILO. Geneve: ILO. Retrieved April 19, 2018, from http://www.ilo.org/wcmsp5/groups/public/---ed_protect/---protrav/--travail/documents/publication/wcms_443267.pdf 
Dokko, J., Mumford, M., \& Schanzenbach, .. W. (2015). Workers and the Online Gig Economy: A Hamilton Project Framing Paper. Washington, DC.: Hamilton Project, Brookings Institute.

EFA. (2005). Understanding education quality, Global Monitoring Report 2005.

EFA. (2005). Understanding education quality, Global Monitoring Report 2005 . ERA.

Engen, E., \& Skinner, J. (1997). Fiscal Policy and Economic Growth. NTJ, 617- 642. doi:10.3386/w4223

Epstein, G., \& GINTIS, H. (1995). International capital markets and national economic policy. Review of International Political, 2(3), 693-718.

Grier, K. B., \& Tullock, G. (1989). An empirical analysis of cross-national economic growth, 1951- 1980. Journal of Monetary Economics, 24(2), 259-276. doi:https://doi.org/10.1016/0304-3932(89)90006-8

Guseh, J. S. (1997). Government Size and Economic Growth in Developing Countries:

A Political-Economy Framework. Journal of Macroeconomics, 19(1), 175-192. doi:https://doi.org/10.1016/S0164-0704(97)00010-4

Hanushek, E. A., \& Ludger, W. (2015). Universal Basic Skills What Countries Stand to Gain: What Countries Stand to Gain? Paris: OECD Publishing.

ILO. (2016). Indonesia Labour Market Outlook. Jakarta, Indonesia: ILO.

Jalal, F. (n.d.). Education Decentralization in Indonesia: Lesson Learned and Challenges. Presentation, Ministry of National Education, Director General for Non Formal Education and Youth. Retrieved from www1.worldbank.org/publicsector/decentralization/hdforum/educationindonesia.ppt

Jalil, A., \& Idrees, M. (2013). Modeling the impact of education on the economic growth: Evidence from aggregated and disaggregated of Pakistan. Journal of Economic Modelling, 31(2013), 383-388. Retrieved January 11, 2017

Kasiry, I. (2009). Kasirye,Determinants of learning achievement in Uganda, Economic Policy Research Centre, Uganda. Economic Policy Research Center. Kampala: Economic Policy Research Center.

Kelly, T. (1997). Public expenditures and growth. The Journal of Development Studies, 34(1). doi:https://doi.org/10.1080/00220389708422503

Kintu, K. (2016). A Thematic Analysis Of The Uganda Lower Secondary School Curriculum: Requirement For Inclusion In Schools. Oulu: Faculty Of Education, University Of Oulu. Retrieved from http://jultika.oulu.fi/files/nbnfioulu-201606042304.pdf

Lock, H. (2015, July 09). Six ways higher education benefits the UK economy. UK. Retrieved January 09, 2017, from https://www.theguardian.com/higher-educationnetwork/2015/jul/09/six-ways-higher-education-benefits-the-uk-economy 
Macaulay, M., \& Syrett, K. (n.d.). Why Major in Linguistics? Retrieved from Lnguistic Society of America: https://www.linguisticsociety.org/content/why-major-linguistics

Mankiw, G., Romer, D., \& Weil, D. (1992). A contribution to the empirics of economic growth. Quartely Journal of Economics, 107, 407-437.

McKinsey Global Institute. (2016). Independent work: Choice, Necessity, and the Gig Economy. Mckinsey\&Company. McKinsey\&Company.

Ministry of Education. (2015). Educating for Our Future. Lusaka: Ministry of Education, Zambia.

Morrill, \& Lincoln. (n.d.). Passing the 1862 Morrill Act . Retrieved from vt.edu: http://www.vt.edu/landgrant/essays/lincoln-morrill.html

Mortimore, P. (1997). Can Effective Schools Compensate for Society? In A. L. Halsey, Education: Culture, Economy, Society. Oxford: Oxford University Press.

OECD. (2011). Education at a Glance 2011: COUNTRY NOTE-GERMANY. Paris: OECD. OECD. (2014). Employability and skills of higher education graduates, EU Skills Panorama 2014.OECD.

Petriglieri, G., Ashfor, J., \& Wrzesniewski, A. (2018, March-April). Thriving in the Gig Economy. Harvard Business Review(March-April ). Retrieved from https://hbr.org/2018/03/thriving-in-the-gig-economy

PricewaterhouseCoopers LLP. (2005). The economic benefits of higher Education Qualifications. Royal Society of Chemistry \& Insitute of Physics. January: PricewaterhouseCoopers LLP. Retrieved January 09, 2017, from https://www.iop.org/publications/iop/archive/file_52061.pdf

Romer, P. (1990). Endogenous technological change. Journal of Political Economy, 98, S71S102.

Rosenholtz, S. (1985). Effective Schools: Interpreting the Evidence . American Journal of Education, 3(3), . 352-388.

Roubini, N., \& Sala-i-Martin, X. (1991). 'Financial Development, the Trade Regime, and Economic Growth . Cambridge: National Bureau of Economic Research. National Bureau of Economic Research.

Rustat-Conference. (2016). The future of work. Cambridge: Jesus College. Retrieved from https://assets.kpmg.com/content/dam/kpmg/fr/pdf/2017/05/fr-Future-Of-Workreport.pdf

Sachs, J. (2015). The Age of Sustainable Development. New Yrok: Columbia University Press. Retrieved from https://cup.columbia.edu/book/the-age-of-sustainabledevelopment/9780231173155

Saleem, F., Naseem, Z., Ibrahim, K., Hussain, A., \& Azeem, M. (2012). Determinants of School Effectiveness: A study at Punjab level. International Journal of Humanities and Social Science, 2(24), 242-251. Retrieved 03 20, 2018 
Sue, W., Bathmaker, A.-M., Gale, T., Hodge, S., \& Parker, S. \&. (2017). Higher vocational education and social mobility: educational participation in Australia and England. Journal Of Vocational Education and Training, 69(1), 147-167.

Sy, A. (2014). Jobless Growth in Sub-Saharan Africa. Washington DC: Brookings Institution. Retrieved from http://www.brookings.edu/blogs/africa-in-focus/posts/2014/01/30jobless-growth-africa-sy

The World Bank. (2018). World Development Report 2018: Learning To Realize Education's Promise. Washington, DC: International Bank For Reconstruction and Development/The World Bank. doi:DOI: 10.1596/978-1-4648-1096-1

UNESCO. (2016). Zambia: Education Policy Review: Paving the Wat to SDG 4-Education 2013. UNESCO.Van der Werf, G., Opdenakker, M., \& Kuyper, H. (2008). Testing a dyanamic model of student and school effectiveness with a multivariate multilevel latent growth curve approach. School Effectiveness and School Improvement, 19, 447-462.

Weber, G. (1971). Inner city children can be taught to read: Four successful Schools.

Washington DC.: Council for Basic Education.

World Bank. (2018). The World Development Report 2018 Learning to Realize Education's Promise. Washington, DC: The World Bank Group. 